\title{
APUNTS SOBRE ELS CONCEPTES DE TEMPS DE JEAN PIAGET
}

\author{
Joaquim Icart Garcia. Àrea de Música. URV
}

\section{Una vella aspiració educativa}

Des de fa unes tres centúries, els camins de la investigació científica han anat assolint unes fites insospitades. També en el camp educatiu pedagogs, psicòlegs i pensadors han esmerçat el millor del seu saber per tal de convertir la tradicional concepció escolàstica de l'educació en una ciència moderna, experimental i dinàmica. El resultat de tot aquest progrés? Passar de l'educació com a art, que preconitzava Plató, a l'educació com a ciència, preconitzada per la moderna pedagogia.

Si durant el s. XIX a Espanya es vivia una confrontació constant entre l'escolàstica i l'enciclopèdia, inaugurada oficialment per les Corts de Cadis el 1812 i continuada en bona part per la històrica institució de Giner de los Ríos, durant el s. XX es van anar consolidant els idearis educatius d'altres il.lustres pedagogs: Montessori, Decroly, Freinet, etc, i a casa nostra, A. Galí, M. Mata, etc., per citar-ne només alguns dels més reeixits. Tots ells $i$ elles, esperonats per l'ànsia de la renovació pedagògica a través d'una escola activa i experimental que fes possible la formació integral dels infants i els facilités una integració a la societat com a ciutadans lliures i responsables.

Ara bé, amb l'experimentació com a eina d'aprenentatge postulada ja pels teòrics del S. XIX no n'hi havia prou. Calia respectar l'infant, tant pel que fa a les seves possibilitats d'aprenentatge com a la seva personalitat. Claparède (1972) ho deia amb aquestes paraules: "Que la pedagogia ha de reposar sobre el coneixement de l'infant tal com la jardineria reposa sobre el coneixement de les plantes, és una veritat que sembla elemental". Ara bé, amb això, ja estava tot fet? No pas! Calia investigar també els mecanismes a través dels quals l'infant realitza tot aquest procés de descobriment sensorial, d'aprenentatge experimental i d'adaptació a la col.lectivitat. Per respectar el creixement de l'infant, calia, a més a més, saber els mecanismes naturals de desenvolupament. Una recerca que no era nova, però que ara es faria amb una metodologia científica, com en qualsevol altre camp del saber. Un estudi on tenen una importància rellevant els treballs realitzats per Piaget, tant per la dimensió científica de les seves investigacions com per la influència que aquestes han tingut en el camp de l'educació.
Tanmateix, al meu parer, hi ha un detall que crec que és molt important $\mathrm{i}$ on aquest brillant pensador no hi va voler entrar: l'espai i el temps com a intuïcions pures de l'enteniment, i com a condició prèvia per a la nostra facultat de pensar, tal com ho havia entès Plató (s.V-IV aC), i va recollir també E. Kant (1970). Així doncs, en aquest treball es vol fer una crítica argumentada d'aquest oblit tot $\mathrm{i}$ reconeixent la immensa tasca realitzada per aquest gran científic i pensador.

De fet, des de finals del s. XVII, amb J. Locke com a figura més brillant, ja s'havia iniciat una nova concepció de l'aprenentatge basat en les dades sensorials com a primer element del coneixement i d'evolució mental. A partir d'aleshores, les recerques, tant a nivell experimental com a nivell reflexiu sobre els actes de coneixement s'han anat succeint d'una manera constant. El resultat de tot aquest progrés? Dràstic! Hem passat de considerar els mecanismes d'aprenentatge de la ment a partir de les idees innates, segons els escolàstics, a considerar-lo, des d'un punt de vista biològic, com un procés d'adaptació al medi, segons J. Piaget. (1982).

Tot plegat, massa lluny d'aquella pastoral Arcàdia sospirada per Rousseau (1983) per al seu Emili, i molt més encara d'aquell estil dialèctic dels clàssics. És lògic, doncs, que enmig d'aquest monumental tràfic d'idees tingui ganes de fer una pausa en el camí. No tant ja per veure'm capaç de trobar la veritat o la raó última de tantes teories, sinó d'intentar albirar amb curiositat els orígens d'aquesta llarga trajectòria, amb l'esperança que, amb una mica de sort, pugui descobrir i degustar aquella sopa d'all de què tant he sentit parlar, i amb ella, el sentit últim de l'educació que s'amaga darrere aquest monumental catering intel-lectual.

El cas és que, en el món de l'art, en general, la matèria que li és pròpia son les vivències personals: els sentiments, les emocions, les passions, anhels i imatges gravades en la substància pròpia de la nostra consciència. Elles són la veritat evident de les nostres vides en el més profund del nostre ser. Doncs bé, començant per aquest aspecte tan essencial al món de les arts, pel que fa a les imatges, la meva impressió és que s'ha desbarrat massa, precisament, des del moment en què van aparèixer les primeres idees sobre la moderna pedagogia al 


\section{g}

segle XVIII, basades en la facultat sensible com a base primera del descobriment del món, a la qual s'unia l'activitat experimental de l'infant en el seu procés d'aprenentatge.

Però no són només les definicions de la naturalesa de les imatges allò que em preocupa. També les definicions dels conceptes d'espai i temps ens toquen de ple, ja que són, considerats ambdós, els medis naturals a través dels quals s'expressen i prenen forma les arts plàstiques i la música respectivament, i perquè llurs diverses consideracions poden arribar a trasbalsar totalment el sentit i l'abast educatiu d'aquestes matèries artístiques, així com els mateixos processos d'aprenentatge i d'exercitació expressiva com a mitjans de formació i realització personal a l'escola.

\section{El paper de les imatges en l'aprenentatge}

L'error cabdal que al meu entendre es va cometre amb les noves teories sobre l'enteniment humà va ser confondre les imatges amb les anomenades idees simples o primeres, les quals, segons J. Locke (1980), provenien directament de la nostra activitat sensorial i eren la base de les futures relacions i formació de les idees més complexes i abstractes, i finalment dels conceptes universals. Només cal donar una ullada a la seva obra per tal d'adonar-nos que aquelles imatges -hom no podrà saber mai per quina de les arts d'encanteri-es dipositen al nostre cap com si d'il-luminacions gòtiques es tractessin, i on hom pot anar a consultar com qui busca un número del BOE a la biblioteca: "No pretendo enseñar, sino inquirir. Por tanto, no puedo sino confesar aquí, una vez más, que las sensaciones externas e internas son las únicas vías de paso del conocimiento al entendimiento que puedo encontrar. Hasta dónde puedo descubrir éstas son las únicas claraboyas por las que la luz se introduce en este cuarto oscuro. Porque pienso que el entendimiento no deja de parecerse a una institución totalmente desprovista de luz, que no tuviera sino una abertura muy pequeña para dejar que penetraran las apariencias visibles externas, o las ideas de las cosas; de tal manera que si las imágenes que penetran en este cuarto oscuro permanecieran allí, y se situaran de una manera tan ordenada como para ser halladas cuando lo requiriera la ocasión, este cuarto sería muy similar al entendimiento de un hombre, en lo que se refiere a todos los objetos de la vista, y a las ideas de ellos".

És clar, Locke intentava esbandir la idea escolàstica de les idees innates i de llur inspiració divina, tot intentant demostrar que no hi havia possibilitat de coneixement si no era a través dels sentits i de la seva educació. Però una cosa és que intervinguin els sentits, i una altra cosa ben diferent és que per aconseguir demostrar la seva teoria, fusioni imatges i idees en una sola cosa. De fet, aquesta descripció és calcada de la que ja havia fet Aristòtil (s. IV $\mathrm{aC}$ ), però aquest ho havia fet respecte dels conceptes ja elaborats per l'enteniment, organitzats en categories, i arrenglerats per a la seva relació a través de l'activitat racional de l'enteniment. Sorprenentment, però, Locke, que hom suposa que coneixia prou bé les agudes apreciacions aristotèliques (que separaven de forma radical la memòria que tenim de les nostres imatges i el record de les nostres idees), tira pel recte i considera tot d'una aquestes imatges-idees, "para cuya recepción la mente se muestra solamente pasiva", com a autèntiques representacions mentals de les nostres experiències sensorials.

De fet, aquest canvi en la denominació del primer responsable de l'enteniment, l'únic que fa és atorgar a les imatges el paper de les idees innates -i d'aquí la confusió-, ja que en l'aparició de les primeres imatgesidees simples, segons hem vist "...la mente se muestra solamente pasiva”. Doncs, bé, aquestes imatges-idees, sorgides de la passivitat en la immediatesa sensorial, mai no podran esdevenir objectes de representació mental de la realitat, i per tant inservibles per a qualsevol relació futura si no és a través d'un procés de diferenciació en dos moments, com a mínim, dins la nostra consciència, i per tant, d'un procés temporal, per més immediat que aquest pugui semblar. I mira per on, sense voler topem amb el problema del temps a través dels moments de la nostra consciència, i alhora amb el problema de l'espai per la convivència simultània però de forma totalment separada: l'objecte i la nostra imatge.

Dos moments, que Hegel (1966) ens els va deixar explicats amb aquella senzillesa i alhora claredat que el caracteritza. Una reflexió que jo ara intento sintetitzar amb aquestes paraules d'exemple: quan noto una sensació, aquesta no pertany a l'objecte mateix que me l'ha tramès (a través de la vista, per exemple, com a sensació del color groc). Aquesta sensació em pertany a mi en la immediatesa de la meva experiència. Jo sóc vertaderament, al moment de l'experiència sensorial, el ser, de la qualitat de l'objecte, i de la noció del groc que he descobert. El ser del groc, la meva noció del groc, no està en el mateix objecte que me l'ha produïda. Ara bé, immediatament rebuda la sensació reconec aquesta noció de groc en l'objecte. Així, doncs, una idea-imatge simple, per més simple que hom la vulgui, sempre necessitarà, com a mínim, de l'acte immediat de la sensació, i de l'acte reflex del reconeixement objectiu de la qualitat. Sense reconeixement objectiu no hi ha idea, ni noció a la qual em pugui referir com a quelcom objectiu i universal. No hi ha idea de groc si no la sé reconèixer en els objectes. 


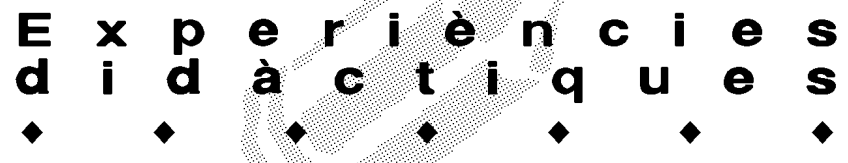

Així doncs, si la ment és passiva en l'experiència sensorial, com podrem fer aquest reconeixement de la qualitat, en la immediatesa del moment de l'experiència? Són necessaris, doncs, dos moments: conèixer i reconèixer, i l'objecte com a tal, per a nosaltres no existeix sense aquest reconeixement. Tal com puntualitzava més exactament Hegel (1966): "De este modo, (referint-se a aquests dos moments) sigue presente aquí lo sensible mismo, pero no como debiera en la certeza inmediata, como lo singular supuesto, sino como universal o como lo que se determinará como propiedad".

És a través d'aquest procés temporal com descobrim la realitat objectiva, l'assenyalem per la seva qualitat posant-li un nom, per exemple, el groc, i ens hi referim en la seva absència. Alhora, per més memòria que tinguin els animals, aquest procés temporal de la reflexió no el fan, i per tant no pensen en l'objecte, ni tampoc els símbols dels llenguatges no els evoquen res. És veritat que poden reconèixer l'experiència sensorial a través d'un senyal sensible, però, que jo sàpiga, encara no he sentit ningú que hagi vist un animal assenyalant una qualitat $a$ través d'una figuració simbòlica.

\section{La intencionalitat de les nostres imatges}

Com a conseqüència primera d'aquest mecanisme en dos moments: el de conèixer i el de reconèixer, podem deduir que d'allò que no ha estat observat, encara que hi hàgim posat els ulls a sobre, però no hi hàgim posat un interès conscient, no en podrem dir res; i així, de quina imatge estaríem parlant?

Husserl (1967) ja ens feia veure que les imatges no són passives, ans al contrari, aquestes porten la càrrega de la nostra intencionalitat. És realment amb la nostra intencionalitat i observació atenta com ens podem proveir d'idees riques en contingut a través de llurs imatges sensorials, i no al revés. Suposem que una persona escolta un interval de 4a. Moltes persones l'hem sentit en multitud d'ocasions a través de l'escolta musical. Tanmateix, si aquesta persona ha prestat atenció en l'experiència sonora d'aquest interval, el reconeixerà tan bon punt l'escolti una altra vegada; amb el benentès, però, que ara no escoltarà la idea de l'interval de $4 a$, sinó que continuarà notant la seva sensació sonora. El que passa és que ara ja reconeixerà la seva noció d'interval de $4 a$ en l'experiència sensorial sonora, o en la nova imatge, la qual cosa no pot passar sense la idea. Si no s'hi ha prestat atenció, ja poden ser quatre-cents milions de vegades que s'hagi escoltat, que la imatge sensorial, per si sola, i més encara si la ment es mostra passiva, tant com deia J. Locke (1980), no hi ha possibilitat d'idea. Igual ens passa moltes vegades que, al no observar un detall d'una cosa, no ens passa pel cap després d'atribuir-lo a l'objecte contemplat. És, doncs, que no hem rebut la seva imatge, o és que no hem pogut fer-nos-en la idea per culpa de la no atenció?

\section{Sobre les imatges i la memòria, i sobre les idees i el record}

Tal com he dit al principi, en aquesta pausa reflexiva he girat la mirada enrere per tal d'assabentar-me del que deien els nostres clàssics sobre aquestes qüestions, i he trobat una observació força interessant de Plató. Per a ell, la imatge era el que reflectia l'esperit, i no pas les il-luminacions gòtiques esmentades anteriorment. Fins i tot, l'univers era la imatge del demiürg, i per aquest motiu s'esmerça a aclarir que la creació del món no és pas una còpia segons un model perfecte, ja que aleshores la perfecció no estaria en Déu. Seria, doncs, el món la imatge del demiürg, l'aspecte sensible del Ser Etern. I com que la ment humana no podria copsar aquest ser tot d'una, va fer el temps, per tal que puguem anar descobrint la seva grandesa de mica en mica, per parts. Veiem, doncs, que el sentit de la imatge en Plató és més que una intencionalitat activa del nostre enteniment; és tota una creació, sentit que Husserl en va acabant fent el leiv motif del seu pensament.

Segons Aristòtil (s. IV aC), les nostres imatges, si bé són impressions sensorials, a través de la nostra memòria o de fer-ne memòria, es donen en el present de la consciència, i per tant no es poden recordar, ja que no podem recordar el present. Així doncs, quina possibilitat de relació entre les imatges-idees de Locke hi pot haver, si es donen en la immediatesa del present, sense possibilitat de desdoblar-se en dos moments encara que sigui només per a comparar-les? El que sí podem recordar són les propietats, però això ja no són les imatges sensorials, sinó el resultat reflexiu de l'observació de l'objecte. És així com una persona pot reconèixer la noció, o la idea d'un interval de $4 a$ en l'experiència sensorial.

\section{Sobre les condicions d'espai i temps del nostre enteniment}

Però no només en les imatges es va desbarrar, crec jo. També en els conceptes d'espai i temps, els quals, volent elevar a nivell científic allò que només era degut a les primeres impressions sensorials, van desembocar en una reducció del seu sentit a pura extensió, relativa a l'espai infinit, i a la seva correlativa duració respecte al temps infinit. D'aquesta manera l'instant era tingut com a correlatiu del punt en l'espai.

De res no va valer l'observació que li va fer a Locke el seu contemporani Leibnitz (1977), tot dient-li que tant el punt com l'instant no són parts ni de l'espai el primer ni del temps el segon, i que ni tan sols tenen parts, ja que només són extrems! Us sona això del punt com a 


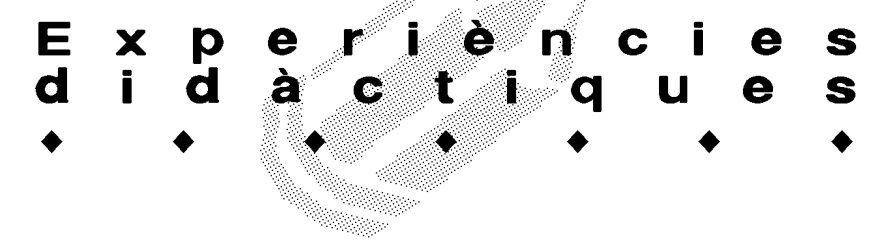

equivalent de l'instant en els cops de la pulsació musical? És possible que aquest error hagi arribat també fins als nostres dies, tot prenent el cop de la pulsació (equivalent de l'extrem d'un segment) per tal de considerar-lo unitat de temps?

També de res o de molt poc van senvir les posteriors observacions de Kant, considerant l'espai i el temps com a intuïcions pures de l'enteniment, tot posant al dia les inqüestionables i evidents raons de Plató, pare de la més perenne de les pedagogies de tots els temps.

I què deia Plató d'aquest espai i d'aquest temps tan enigmàtic perquè Kant el prengués com la primera condició de l'enteniment? Molt senzill: Estava Sòcrates explicant-li a Glaucó el que primer es necessitava per a poder comprendre les coses, i li va posar aquests dos exemples:

El primer anava així: Si em miro els dits de la mà, els sentits només em poden informar del seu tacte, de si són durs, de si són flonjos, però no pas de si són curts o llargs; això només m'ho pot dir l'enteniment tot comparant les diferents llargades per mitjà de la reflexió. Ara bé, hem d'entendre que aquestes dades per als sentits són simultànies, però l'enteniment no les confon, i és capaç de veure per separat allò que es dóna alhora.

El segon anava així: Si hom agafa un pes, podrà dir si és molt pesat o no. Això ho podrà dir comparant-ho amb una altra experiència anterior. Els sentits només ens poden informar del pes, però no del més o menys. Doncs bé, ara hem de considerar que les dades dels sentits ho han estat en moments diferents, però la ment ha estat capaç de considerar-les simultàniament, també sense confondre-les.

Segons això, Plató volia explicar que el principi de la capacitat de l'enteniment està a poder veure per separat allò que els sentits ens donen simultàniament, i de poder veure simultàniament allò que els sentits ens han informat en moments diferents. I en aquesta direcció Kant (1970) va definir també els principis de l'enteniment.

\section{Un pas enrere molt important}

Piaget (1978), contràriament a Locke per pura lògica, va separar clarament les imatges de les idees: "...establecer una distinción entre las percepciones instantáneas, con sus características siempre receptivas, y una actividad perceptiva que la una unas a las otras, en el espacio y en el tiempo, según ciertas leyes notables (particularmente una movilidad y una reversibilidad que aumentan con la edad)". Ara bé, aquesta activitat perceptiva l'atribueix a "las actividades sensomotrices cuya expresión constituye la inteligencia preverbal".

D'aquesta manera, en ple segle XX, J. Piaget es va encarregar de llençar en orris aquelles sàvies apreciacions sobre l'entitat pura de l'enteniment, considerant l'espai i el temps com quelcom extern a través dels quals se succeeixen els esdeveniments interns de l'enteniment. Segons Piaget (1982) no s'arriba a l'a priorikantià fins al final del procés evolutiu, o el que és el mateix, al final del procés d'adaptació al medi. L'espai i el temps són conceptes físics, als quals s'arriba a partir de les primeres intuïcions internes de duració, i la seva objectivació progressiva. En aquest cas, tampoc no van servir de res les agudes i sàvies observacions de Bergson (1927) respecte al sentit espacial i temporal de l'enteniment, assumint els mateixos criteris de Plató i de Kant.

Al meu entendre, per la seva fixació en el fet que el desenvolupament era, abans que res, un procés d'adaptació genètic, J. Piaget mai no va copsar el sentit del temps i de l'espai kantià i platònic, ni el va aplicar en l'observació dels seus experiments, ni menys encara es va entretenir a discutir d'una forma racional els arguments en aquest sentit, que de forma tan didàctica li mostrava la gran figura del pensament, del seu contemporani Bergson. Ans al contrari, el va criticar durament i es va oposar frontalment a les seves investigacions sobre la qualitat espacial $i$ temporal de l'operativitat mental. O potser sí que ho va copsar, però la seva acceptació contrariava tota la seva teoria d'adaptació a través dels agrupaments, seriacions, etc.

\section{Les meves apreciacions sobre aquest conflicte conceptual}

Per aquest motiu, i pel fet que l'activitat mental en la pràctica musical té molt a veure amb les apreciacions platòniques, kantianes i bergsonianes, em permeto qüestionar un dels experiments més coneguts que J. Piaget, en col-laboració amb B. Inhelder (1981), va realitzar en una població infantil corresponent al segon estadi de la seva classificació evolutiva. Es posava l'infant assegut en una cadira. Davant seu i damunt la taula, hi tenia una placa quadrada d'uns $40 \mathrm{~cm}$ de costat. Els infants, de 3-4 anys, havien de reconèixer pel tacte una sèrie d'elements que se li posaven pel darrere d'aquesta placa i assenyalarlos després al dibuix que hi havia a la pissarra. En una primera tanda, havien de tocar objectes casolans que se li posaven a les mans, i en una segona, objectes senzills geomètrics: triangle, quadrat, cercle, el-lipsi i rombe. En la primera tanda, els infants reconeixien sense problemes aquests objectes. En la segona tanda, però, en el reconeixement de les figures geomètriques, per més senzilles que fossin, els resultats ja no eren tan bons. Per què, doncs, aquesta dificultat?

Doncs bé, això tan senzill que pot semblar a primera vista, els infants no ho podrien fer si no poguessin objectivar alhora la nostra intuïció d'allò que és "dalt" i "baix", "dreta" i "esquerra". Sense aquest sentit d'orientació bé podríem haver considerat les puntes d'un triangle en filera, una al costat de l'altra, i no pas en la posició que els correspon 


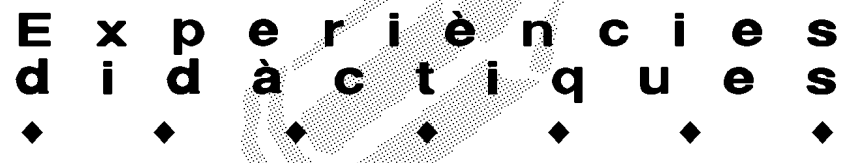

en l'estructura triangular. Ara ja no es tractava d'una simple diferenciació a partir de dades purament sensorials (els vèrtexs d'un triangle equilàter són, a més a més, tots iguals). Ara calia identificar una forma a partir de les seves parts estructurals. Les dades per a la seva identificació no entraven pels sentits, sinó a través de l'exploració.

I en què consisteix exactament aquesta exploració? En el fet d'adonar-se, a través de la sensibilitat tàctil, de la forma de l'objecte amb l'anàlisi de les seves parts i de la seva posició respectiva. Una relació entre parts que només es podia efectuar correctament si es podien considerar simultàniament (o sigui, espacialment) les diferents parts del triangle, distingides, una a una, de forma discreta, per la facultat temporal.

Imagineu-vos que la persona que ha d'identificar el triangle, pel motiu que sigui: per la grandària del triangle respecte a les mans, per una exploració inacabada, o senzillament, perquè l'exploració es queda en una simple constatació de parts sense relació entre el principi i la fi de la seqüència formal. En aquests casos la síntesi formal no seria possible.

J. Piaget (1981) no va estudiar pas la problemàtica temporal de la ment en els infants a través dels moments discrets de les seves exploracions. Tot al contrari, ho va considerar unilateralment com el desenvolupament de la capacitat de representació de l'espai, a partir dels resultats dels agrupaments i esquemes operatius assolits: seriacions, encaixos, etc., i no pas en l'anàlisi de les condicions mentals que ho feien possible. Per aquest motiu es preguntava per la curiositat que els infants més petits eren capaços de reconèixer objectes quotidians més complicats formalment, abans que figures tan senzilles com el triangle; experiències quotidianes que comparava amb l'espai topològic dels matemàtics, el qual ha estat una de les últimes conquestes d'aquesta disciplina.

És clar, reconèixer una pinta, una clau, etc, és possible només a nivell sensorial. No fa falta cap observació, sinó només constatació a través de la imatge que es fa present de forma immediata a través de l'experiència sensorial, i no té cap connotació matemàtica, ni de lluny! Això ho poden fer també els animals superiors, i bé que ho sap la policia, a l'hora d'identificar objectes en els processos d'investigació. En lloc d'aquesta observació tan elemental, J. Piaget (1981) va optar per considerar el procés de reconeixement de les figures geomètriques i de l'espai, en general, com una continuació d'aquest procés de reconeixement topològic de les formes, i així, els successius avenços no els va considerar sota els paràmetres de la capacitat de síntesi espacial dels moments discrets de les exploracions, sinó com un procés d'estructuració mental de l'espai físic. I cosa curiosa, també ho va considerar així en el mateix procés d'estructuració mental del temps, malgrat que la capacitat de l'ordenació temporal, que Piaget (1978) intenta explicar com s'adquireix, ningú no la pot fer sense aplicar, precisament a priori, aquesta capacitat espacial i temporal de què estic parlant.

\section{El nus gordià del temps piagetià}

El drama de la teoria piagetiana, al meu entendre, s'origina a l'hora d'interpretar les intuïcions espacials i temporals pures del nostre enteniment, que havia definit Kant (1970) sota el seu esquema biològico-evolutiu. I per tal de no provocar suspicàcies o interpretacions errònies, em permeto transcriure un petit comentari seu sobre aquesta qüestió: "Como profundamente ha sentido Kant, el tiempo no és un concepto, es decir, una clase de objetos múltiples, sino un esquema único, es decir, una forma de conjunto común a todos los objetos 0 , si se prefiere, un objeto formal o una estructura. Sólo que, por el hecho de que el tiempo no es una clase lógica, Kant llegaba a la conclusión de su naturaleza intuitiva".

Al meu entendre, aquesta lliure i espontània conclusió -per no dir-ne gratuïta- que de la intuïció pura de Kant en fa Piaget ens inclina a fer-nos creure més en una claudicació kantiana -o fins i tot en un fracàs d'aquella lògicaque no pas en una conclusió racional. Hom es pot preguntar, doncs, per quin interès especial, i amb tan poc rigor dialèctic, despatxa aquest problema, per altra part cabdal, no només a la història del pensament, sinó també de la pedagogia. És curiós, a més a més, que Piaget no hagués fet cap estudi sobre l'estructuració de la mètrica musical interna, ni tan sols del ritme a nivell psicomotriu, tal com ho va fer amb el raonament matemàtic o el discurs verbal.

Però, és clar, per a Piaget el temps era un concepte relatiu a la velocitat i a la distància, i segons la seva teoria d'acomodació al medi, aquest concepte s'assolia a partir de les activitats sensomotrius, les quals, com hem vist anteriorment, suplirien la funció de la capacitat espacial i temporal del nostre enteniment. El que passa realment és que, en lloc de contemplar el procés evolutiu des d'unes condicions prèvies de l'enteniment humà, com era el cas de Plató i de Kant, ara el contempla des d'un punt de vista purament biològic, considerant les condicions primeres prèvies a la mateixa activitat sensomotriu. Així doncs, el que no ha quedat mai explicat, segons la teoria piagetiana, és com s'aconsegueix realment, i sense els seus artificis, el pas cap a la representació mental i la capacitat operatòria de la nostra ment.

De fet, a Piaget (1978) no li toca altre remei, a efectes pràctics, que considerar les imatges de la mateixa manera que ho va fer Locke. I si bé es veritat que reconeix les imatges com un cúmul immediat i sintètic d'experiències: "...cada porción del continuo temporal interior 


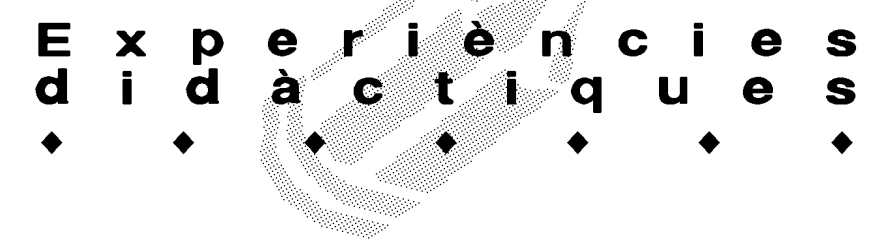

aparece como un tejido de acontecimientos simultáneos, como una 'instantánea' en el sentido en que se emplea esta palabra en la fotografía de un sistema físico cualquiera", no té en compte que aquella instantània, per si mateixa, no ens permet de fer-ne una anàlisi de les seves parts, ja que no és quelcom objectiu que podem observar, sinó només una consciència, en la immediatesa del present.

Per no voler reconèixer aquell a priori de les nostres intuïcions pures espacials i temporals, que ens permeten l'activitat discreta del continu de la nostra sensibilitat, no li toca més remei que desentendre's com sigui del problema de la immediatesa de les imatges, i prenent-les, gratuïtament ara, com quelcom representable, no hi veu cap inconvenient a considerar-les, a elles mateixes, com qualsevol objecte sobre el qual s'hi pugui operar; en un sentit virtual, és clar (exactament com feia Locke amb les idees respecte de les imatges). Així afirma, a continuació de l'anterior citació: "Reconstruir una serie de acontecimientos internos será siempre, pues, construir una coseriación". És cosa notable que un investigador de la seva talla no s'adoni que de l'instant passiu d'una imatge rebuda, segons la seva pròpia teoria, no en pot sortir cap coseriació.

I és que Piaget va confondre de tal manera el temps intern amb l'extern que no va ser capaç d'entendre el sentit de la intuïció temporal dels moments de la consciència. Heus aquí l'exemple més clar: "El tiempo es creación o no es absolutamente nada", ha dicho también Bergson, y ello és la verdad misma, pero con la condición de precisar que el trabajo espiritual no se traduce en duración, como el "trabajo" físico, más que en relación con su potencia (y por tanto, con su rapidez). Que esta traducción vaya acompañada de errores sistemáticos bien conocidos, según los cuales el trabajo rápido o intenso parece corto durante el instante vivido, y largo en la retrospección...". Claríssim, per a Piaget el temps intern només és una sensació relativa a una experiència de duració externa.

\section{Els arguments musicals salven Piaget del seu inde- mostrable temps psicològic}

Així, havent posat dins d'un mateix sac el temps físic i el psicològic, relatius ambdós a la velocitat i la distància, J. Piaget (1978) es pregunta: "Las operaciones del tiempo psicológico se limitan en general a lo cualitativo puro. Pero, ¿no existe una métrica temporal interna? Las imágenes más bellas en que abunda la obra de Bergson están tomadas de la música y, cuando ese maestro de la introspección quiere explicar lo que la duración creadora comporta de irreductiblemente intuitivo e irracional, se expresa en términos de melodía, de ritmo y de sinfonía". "El ritmo musical es, puede decirse, la más directamente intuitiva de las métricas temporales, y ciertamente no es desde el mundo exterior desde donde se ha impuesto a nosotros". És clar, la mètrica musical és només una intuïció irracional, i per tant no hi va perdre ni un minut a esbrinar què hi havia realment darrere seu.

Però, alhora, al no saber ni poder dir-ne res sobre la possibilitat de coseriacions sorgides de dins mateix del caràcter sintètic de la imatge, J. Piaget fa una excursió al món de la música per tal de prendre en préstec, precisament de Bergson, la capacitat discursiva i discreta d'aquesta, i així poder argumentar la mètrica temporal també a nivell subjectiu sense malmetre la seva teoria. Però segurament ni així Piaget no es va adonar que la mètrica musical només és possible gràcies a la capacitat temporal a priori del nostre enteniment, la qual li permet diferenciar de forma discreta els moments, ja siguin a nivell de duració interna o externa, ja que la discrecionalitat no és cap propietat del temps, ja sigui físic o subjectiu, sinó que és el temps mateix el que descobrim a través de la nostra capacitat discursiva. En la immediatesa del present, sense la capacitat de diferenciar moments de la consciència present, i poder-los sumar després o dividirlos en parts, el temps, ja sigui extern o intern, no té sentit.

Per totes aquestes qüestions, vaig voler comprovar si realment aquests moments de què he parlat tan insistentment eren tan importants dins el procés mental. Així, vaig intentar convertir els moments sensorials, o els moments de les imatges, en quelcom visible i observable físicament.

Vaig construir una capsa en metacrilat transparent,

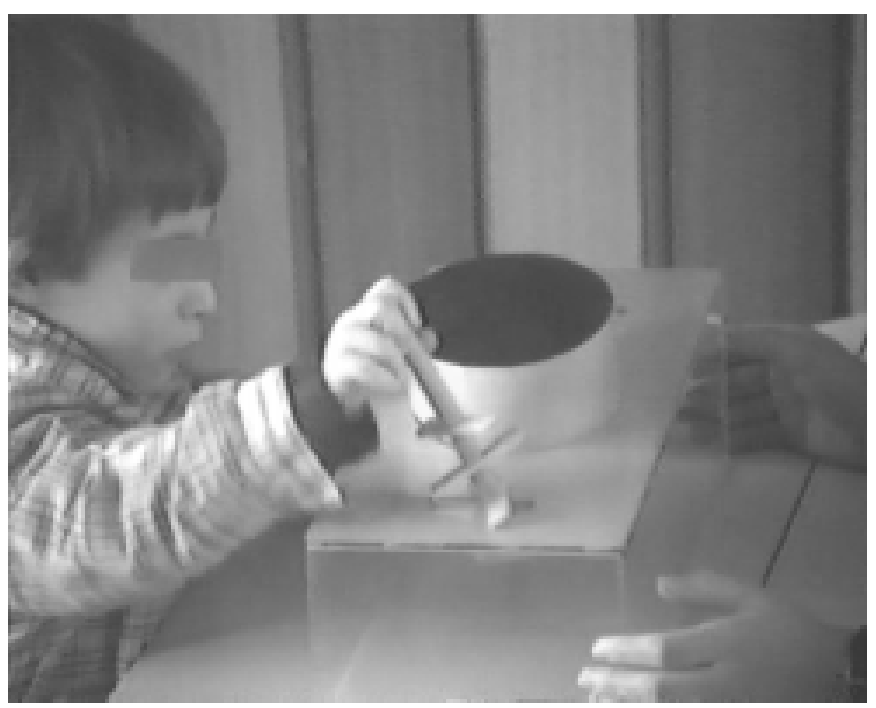

Foto 1. Els infants es bloquejaven al no poder coordinar per separat les diferents direccions de les fustes travesseres. 


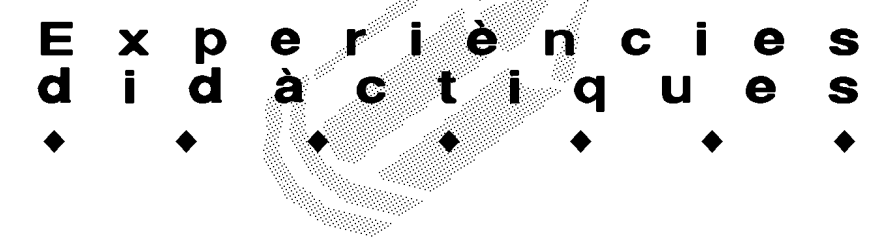

menys en la cara superior, que era opaca. A la tapa hi vaig fer tres orificis pels quals els infants havien d'introduir altres tres objectes. Ara bé, per introduir-los, havien de coordinar, com a mínim, dos moments, els quals estaven explicitats físicament en els mateixos objectes: per un orifici rectangular hi havien d'introduir un bastó de forma cilíndrica, el qual estava travessat per unes plaquetes de la mateixa forma que l'orifici. Per un altre orifici, hi havien d'introduir un cilindre de base el-líptica, de superfície igual a la de l'orifici. Per un tercer orifici, hi havia d'introduir un objecte en forma de "s".

La dificultat del primer exercici consistia en el fet que, una vegada havien començat a introduir el bastó amb la primera placa, la segona que seguia tenia una altra direcció, i la tercera una altra... Així, s'obligava l'infant a separar cada moment de l'operació, per tal d'anar introduint totes les plaques travesseres, encara que totes les plaques del bastó les veiés alhora.

La dificultat del segon exercici consistia en el fet que les bases el-líptiques del cilindre estaven una respecte de l'altra formant un angle d'uns $30^{\circ}$. Així, si es fixaven en la base inferior per fer-la coincidir amb l'orifici, es trobaven que a mig camí no podien seguir, ja que la base superior quedava travessera. Però si feien coincidir la part superior del cilindre amb la direcció de l'orifici, aleshores era la base inferior la que quedava travessada i no la podien fer entrar.

La dificultat del tercer exercici consistia en el fet que l'objecte en forma de "s" se li donava a l'infant en la posició invertida, de forma que encara que la fes girar horitzontalment tots els $360^{\circ}$ mai no la hi podia fer entrar. La

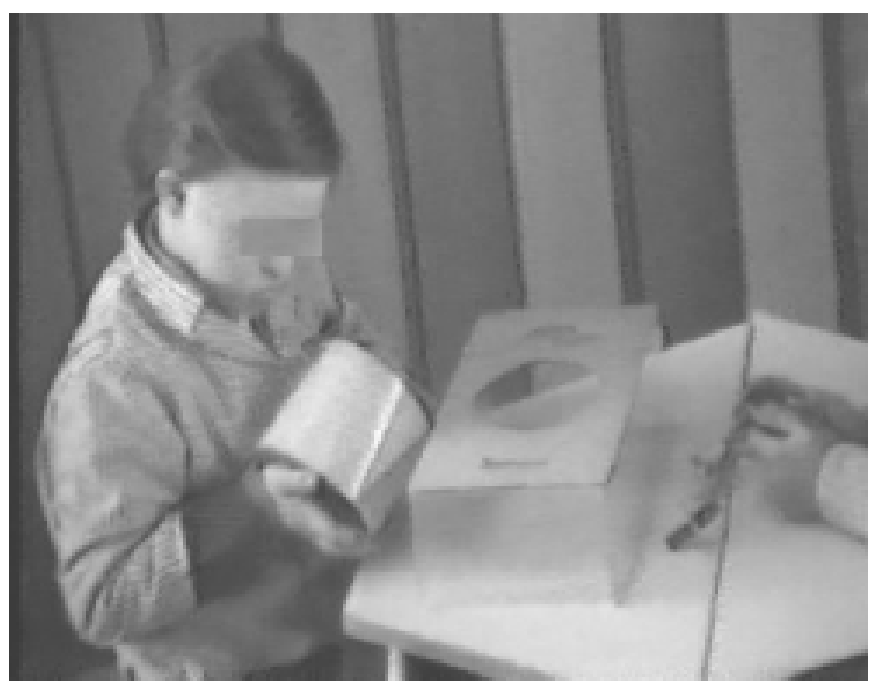

Foto 2. Un infant explorant les bases del cilindre. No eren capaços la majoria de fer-se presents alhora les dues bases que havien de veure per separat. solució consistia a donar la volta a l'objecte, però aleshores l'infant havia d'intuir la forma simètrica que quedaria després de donar-li la volta, la qual cosa comporta la relació de dos moments, un de visible, i l'altre de virtual.

L'experiència es va passar a nens i nenes d'entre $4 \mathrm{i}$ 5 anys, corresponent també al segon estadi, en una població escolar sense problemes d'aprenentatge, i entre una població escolar amb infants discapacitats amb edats compreses entre els 9 i 11 anys, però que es corresponien amb l'etapa preoperatòria de què ens parlava també Piaget.

Doncs bé, les dificultats eren ben visibles en més d'un $30 \%$ de la població normal, i d'un $90 \%$ entre la població amb dificultats d'aprenentatge. D'on venien, doncs, tantes dificultats si ara els infants tenien els objectes a la vista i els podien manipular tant com volguessin? Penso que és força creïble que la dificultat no es trobava en la forma de l'objecte, (no es tractava de reconèixerla), sinó en la seva manipulació en ordre a una operació que comportava la coordinació de dos o més moments de l'enteniment.

Aquestes consideracions crec que són molt importants per als qui ens dediquem o dedicarem a preparar i conduir l'exercitació musical dels més petits, ja que la sola entitat sonora dels elements constitutius de la forma musical: ritme, melodia, i harmonia, no aguanten la mínima interpretació dels postulats piagetians, mancats com estan de les premisses espacials i temporals del nostre enteniment. Al meu entendre, les teories de J. Piaget sobre l'espai i el temps no fan sinó embolicar encara més la troca de la ja secular confusió en l'apreciació psicològica de l'espai i del temps. Ambdós conceptes necessiten ja, a priori per a la seva assimilació, de les intuïcions pures del nostre enteniment, que fan possibles diferenciacions discretes de la nostra consciència (sempre aquest present continu), del record d'aquestes i de la capacitat de la consideració simultània però no confusa de les seves parts.

Recordo que aquestes i altres experiències meves les vaig realitzar en col-laboració amb Antoni Cambrodí, amic personal de Piaget, amb els principis del qual aplicava les seves estratègies d'aprenentatge en una població infantil especial.

Recordo també que, amb una humilitat i sinceritat pròpia només de les grans persones, va confessar-me que no era capaç, encara, d'aplicar de forma correcta la teoria de Piaget. Per la meva part li deia que els infants havien d'exercitar-se musicalment per tal de potenciar la capacitat de relació espacial i temporal de l'enteniment que he defensat en aquest escrit.

Cambrodí, amb tota l'honestedat d'un gran home, va explicitar públicament aquell desencant, el qual, però, 


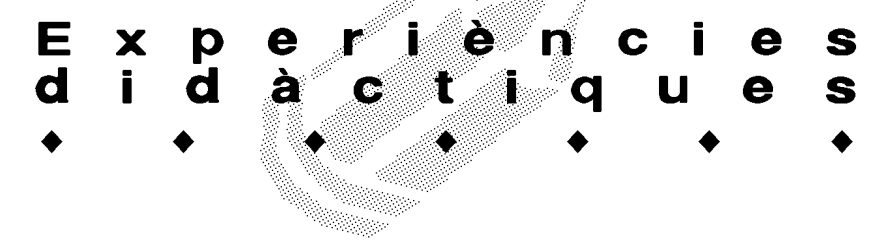

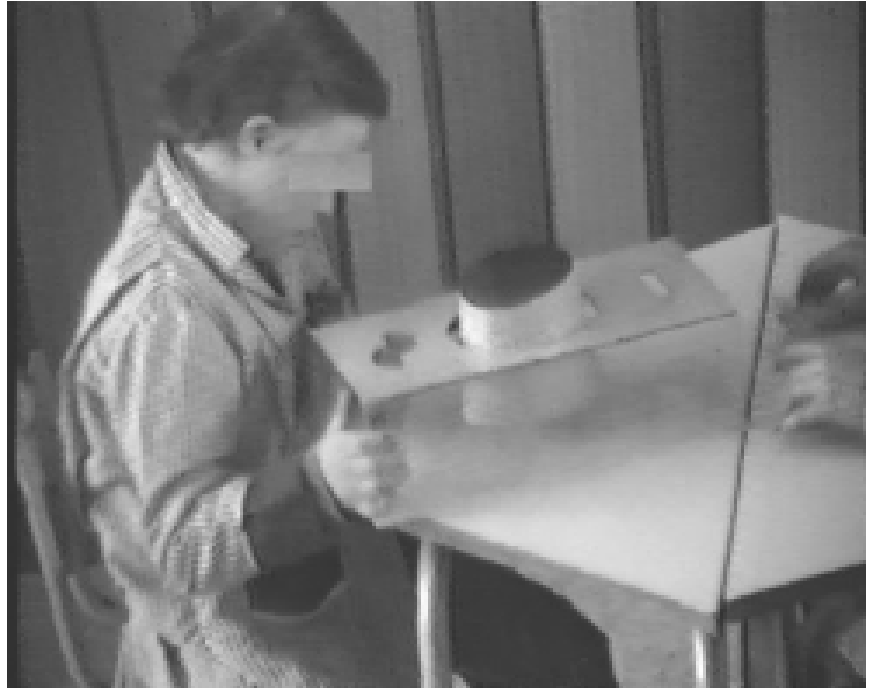

Foto 3. El mateix infant que el de la foto 2 , bloquejat a mig camí de l'operació. El problema rau en la dificultat externa del procés d'acoblament, o bé en la interna, per no ser capaç de coordinar simultàniament dos moments discrets?

lluny de significar-li una claudicació, era un esperó que li donava noves forces per continuar traient-ne l'entrellat del nostre misteri mental: "¿Por qué razón no sobrepasan nunca estos seres, en el desarrollo de su inteligencia, los límites del período que Piaget ha descrito como preoperacional? Si el despliegue de la misma es el resultado de la acción sobre el medio, ¿cuáles pueden ser las particulares circunstancias que se dan en aquel intercambio? ¿Es de verdad el deficiente mental un ser «original», producto fatal de una maduración considerada «atípica»?".

Al meu entendre, segueix sent aquesta capacitat a priori o causa primera de la possibilitat de coneixement de què ens va parlar Plató, i que tan brillantment va prendre Kant com a flama il.luminadora del pensament modern, allò que hauria d'il.luminar també les nostres passes com a educadors, utilitzant més la dialèctica amb els infants, i que ells mateixos la prenguessin com a mètode d'experimentació i aprenentatge, i no tant de seguir amb passos de cec el que potser només ha estat una de tantes idees lluminoses metodològiques en la història de l'educació. Pel que fa als músics, l'aprenentatge i l'exercitació musical potencia, i fa més capaç en les seves funcions el nostre enteniment, ja que la simple activitat de notar i representar-nos els moments discrets de la pulsació, objectivar-los en tantes unitats de duració com ens convingui tot mantenint el valor objectiu de la seva duració a través del continu temporal present, dividir-lo en fraccions, etc., en definitiva, estar per més de dues coses alhora sense confondre-les i de manera coordinada, no és res més que un exercici pur de la intel.ligència. Això, a part dels beneficis espirituals, de joia i de benestar que se'n deriven. I això, per al món musical, sempre ha estat així, i que duri!

Em fa l'efecte que al final he retrobat el gust d'aquella primera sopa d'all de què tantes vegades he sentit parlar!

\section{Referències bibliogràfiques}

ARISTÒTIL. De la memoria y el recuerdo. Traducció de Francisco de P. Samaranch. Ed. Aguilar. Mexico. 1980.

BERGSON, H. Essai sur les données immédiates de la conscience. Edit. Quadrige/Presses Universitaires de France. Paris. 1982.

CLAPARÈDE, E. Psychologie de l'enfant et pedagogie expérimentale. I. Le développement mental. Edit. Delachaux et Niestlé. Neuchâtel et París. 1972. Pàg. 71.

HEGEL, G. W. F. Fenomenologia del espíritu. Traducció de Wenceslao Roces. Edit. Fondo de Cultura Económica. México. 1966.

HUSSERL, E. Investigaciones lógicas. Traducció de Manuel Morente. Revista de Occidente. Madrid. 1967.

KANT, E. Crítica de la razón pura. Traducció de J. B. Bergua. Edit. Clásicos Bergua. Madrid. 1970.

LEIBNITZ, G. G. Nuevo tratado sobre el entendimiento humano. Edit. Porrúa. México. 1977.

LOCKE, J. Ensayo sobre el entendimiento humano. Traducció d'Esmeralda Garcia. Editora Nacional. Madrid. 1980.

PIAGET, J. El nacimiento de la inteligencia en el niño. Traducció de Luis Fernández Cancela. Aguilar Ediciones. Madrid. 1982.

PIAGET, J. La formación del símbolo en el niño. Fondo de Cultura Económica. México. 1980.

PIAGET, J. La construcción de lo real en el niño. Traducció de Mabel Arruñada. Ediciones Nueva Visión S.A.I.C. Buenos Aires. 1982.

PIAGET, J. La dirección de los móviles. Traducció de Raúl Gustavo Aguirre. Ed. Troquel. Buenos Aires. 1974.

PIAGET, J. El desarrollo de la noción del tiempo en el niño. Traducció de Víctor Manuel Suárez i Juan José Utrilla. Edit. Fondo de Cultura Económica. México. 1978.

PIAGET, J. i.INHELDER, B. La représentation de l'espace chez l'enfant. Edit. Presses Universitaires de France. Paris. 1981.

PLATÓ. La República. Edit. Fundació Bernat Metge. Barcelona. 2000.

ROUSSEAU, J. J. Emilio o la educación. Traducció de F. L. Cardona. Edit. Bruguera. Barcelona. 1983. 